\title{
4 Principles of the Edition
}

\subsection{Text}

This critical edition of Magentenos' commentary on Anal. Pr. II is based on the text of $\mathrm{V}$ and $\mathrm{D}$. U was taken into account with regard to the twenty-eight scholia shared verbatim by both the recensio vulgata and the recensio Urbinatis, namely the comments in the fourth group (see p. LXXIV; on the notation of these comments in the text of the edition see p. LXXXII). The remainder of the recensio Urbinatis (i.e. groups 1-3, 5-6) is considered only when they transmit better readings than the vulgata. For a complete collation of the recensio Urbinatis Appendix E may be consulted. Variant readings in other textual witnesses are noted only when they offer salient conjectures. $\mathrm{V}$ is pre-

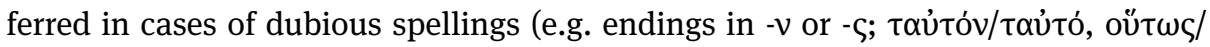

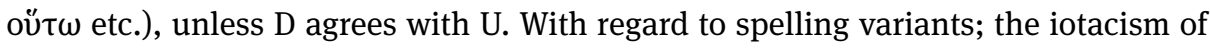

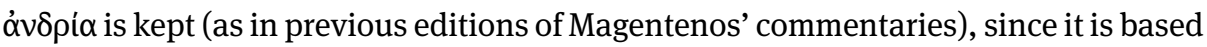
on the textual tradition of the Anal. Pr. during the eleventh century and does not construe a different meaning (see below p. LXXXIX). ${ }^{1}$

The comments of Magentenos share a common syntactical characteristic present in Byzantine texts - the replacement of the future indicative with the aorist subjunctive in conditional clauses introduced by ci. $^{2}$ There are also syntactical peculiarities in concessive and temporal clauses due to the relation between the two moods:

- $\quad \varepsilon \grave{\imath}+$ aorist subjunctive (+ future indicative) ${ }^{3}$

- $\quad \varepsilon \dot{\imath}+$ aorist subjunctive, future indicative with ớv in the apodosis ${ }^{4}$

- $\quad \varepsilon \dot{\alpha} v+$ present indicative ${ }^{5}$

- $\quad$ kő $v+$ present indicative ${ }^{6}$

- $\quad$ ö $\tau \alpha \nu+$ present of future indicative ${ }^{7}$

- ŏ $\tau \varepsilon+$ present subjunctive ${ }^{8}$

These peculiarities are retained in our edition and are taken into consideration when making corrections.

While Greek numbers for the comments in $\mathrm{V}$ are provided by the scribe himself (see p. LXII), the enumeration of comments in our edition uses bold arabic numerals.

1 The word is written with - $\mathrm{I}$ - in V, but it has been corrected in D and U.

2 Funk 1961, 188-189; Kotzabassi 1999, 60; Stone 2009, 129; see e.g. scholia 22.1-2, 51.3, 67.1-2, 108.1.

3 Funk 1961, 193; Kotzabassi 1999, 60; see scholion 141.16-19.

4 Stone 2009, 131; see scholion 156.6-7.

5 Funk 1961, 190; see scholia 20.4, 91.1.

6 Funk 1961, 190; see scholion 20.7-8.

7 Funk 1961, 193; see scholia 15.1, 45.2, 93.1, 131.4. In one instance an aorist subjunctive follows a future indicative verb; see scholion 142.12-15; Funk 1961, 193; Kotzabassi 1999, 60; Stone 2009, 126.

8 Funk 1961, 193; scholion 118.1-2. 
These are printed before the relevant Bekker page number for each lemma. In addi-

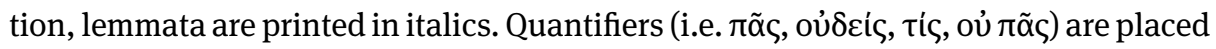
inside curly single quotation marks (' '). Words or statements employed as either explanatory formulations, as examples, or as sentences of a dialogue are also placed inside curly singe quotation marks. Additions are printed within angle brackets $(\langle\rangle)$. Omissions are printed within square brackets ([]). Editorial conventions regarding additions of Greek text are not printed in the translation. Added lemmata are not translated. If two or more scholia refer to the same passage in Anal. Pr. II, then the relevant Bekker page and lemma (unless the latter is transmitted by the manuscript tradition) are printed only before the first scholion. As the punctuation does not follow any set rules in any of the manuscripts, modern usage has been adopted. The only exception is the combination of colon and en-dash (:-) for signifying the end of a scholion. Correspondance to the folia of the editio princeps is indicated in the outer margins of the comments and the mark // in the Greek text.

Furthermore, the following system of conventions (in the Greek text only) serves a dual purpose:

1. The documentation of the relative position of the scholia in both hyparchetypes of the recensio vulgata, i.e. to provide information regarding the structure of the final version of the commentary by means of notation within and at the end of the text of a scholion. The traditional apparatus note would require more space, while it does little to draw the attention of the reader to this kind of information. In the case of Magentenos' text, in fact, this may apply to indicating cases of possible interpolation already existing in the archetype (or its exemplar) or to distinguishing different phases of successive filling up of marginal or interlinear scholia (see p. LXV). Examples of notation:

(a) At the end of scholion 227: ' $[\Leftarrow 225]$ ' = 'see comment 225 for information regarding the position of scholion 227 in the sequence of text in one of the hyparchetypes'.

(b) At the end of scholion 135: '[V a.c., $D \Rightarrow 141]$ ' = 'here follows comment 141 in V ante correcturam and D'. A note of the type ' $[\Leftarrow 135]$ ' should then be printed at the end of comment 141.

(c) At the end of scholion 221: '[(221-222) V]' = 'comments 221 and 222 form a single item in the order indicated inside the brackets'. A note of the type ' $[\Leftarrow 221]$ ' is then printed at the end of comment 222.

(d) At the end of scholion 145: '[oD]' = 'comment 145 is omitted in D'. This kind of notation at the end of a chapter title means 'chapter omitted in D'.

(e) In the text of a scholion: '[/V]' = 'here begins a new comment in V'; see for instance scholion 75.3 .

2. The documentation of scholia belonging to one of the six scholia-groups of the recensio Urbinatis presented on p. LXXIV. Examples of notation at the end of the respective scholia: 
(a) '[U-]' = 'comment belonging to either the first, or the second group'.

(b) ' $[\approx \mathrm{U}]$ ' = 'comment belonging to the third group'.

(c) ' $[=\mathrm{U}]$ ' = 'comment belonging to the fourth group'.

(d) ' $[\mathrm{U}+]$ ' = 'comment belonging to either the fifth, or the sixth group'.

Concerning the English translation of the Greek text and in order to maintain consistent English terminology in the field, particularly with reference to Aristotelian lemmata and terminology, we have consulted the revised 'Oxford Translation' by Jonathan Barnes and the translations of Robin Smith and Gisela Striker. ${ }^{9}$

\subsection{Apparatus}

At the bottom of each page of Greek there are three sets of notes, the apparatus diagrammatum, the apparatus criticus and the apparatus fontium. The first apparatus contains always the lemma and the number of the respective diagram in Appendix A. The apparatus fontium includes references to sources and parallela as well as cross references. Among the references of this apparatus is included further information concerning the three paratexts in Appendix $D$ (orthography and accentuation have been normalized). These short excerpts deal with the aim of Anal. Pr. II. They are thus of special interest with respect to the views expressed in schol. 1. In the apparatus criticus the Aristotelian variants are followed by the indication 'Arist.' and the respective siglum or sigla placed in brackets, e.g. [variant] Arist. (nC).

\subsection{Diagrams}

Diagrams were paratextual material employed in the manuscript tradition of Aristotelian treatises in order to explain and/or summarize difficult passages. Such figures not only enhanced the reader's understanding of an inconvenient technical text - as in the case of the Anal. Pr. - but they also functioned as visual memory aids. ${ }^{10}$

However, every effort either to edit diagrams, or to restore them in their relation to a commentary should always take their sources into account. There are five essential difficulties:

- As we have shown in the case of the interpolated recensio Urbinatis, diagrams may find themselves rendered as text in later versions of a commentary (see p. LXXIV).

9 Barnes 1984, Smith 1989, Striker 2009. For the text of the 'Oxford Translation' see Jenkinson 1928. A fourth English translation of Anal. Pr. can be found in Tredennick 1938.

10 For the use of logical diagrams in Greek manuscripts, see e.g. Brumbaugh 1961; Brumbaugh 1965; Brumbaugh 1968; Bülow - Ebbesen 1982, 50-51; Panizza 1999, 22-47; Cacouros 2001, 21-33; Prapa 2012, 31-41; Rambourg 2012, 1-36; Agiotis 2015, passim; Agiotis 2021b; Krewet - Hegel 2021b. 
- Diagrams in source ' $x$ ' may be drawn differently in source ' $y$ '.

- Diagrams were culled from different sources (see Table 1 below).

- Similar captions or complete lack of wording in a diagram may make determining its text source difficult, even if it should be the commentary at hand.

- The transmission of diagrams does not always go hand in hand with the transmission of text. To use Magentenos as an example, three out of twelve manuscripts that transmit the whole or large sections of the commentary on Anal. Pr. II do not contain any diagrams at all (see stemma codicum on p. LXXIX). Magentenos himself twice insinuates the general principles for drawing a diagram (schol. 219,

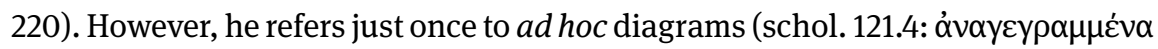
oxń $\alpha \alpha \alpha)$. It must be noted, however, that in this last case the manuscript tradition transmits no diagram pertaining to the relevant passage. Morever, Magentenos makes no reference whatsoever to the rest of the diagrams edited in this current volume.

For the present edition the logical diagrams present in $\mathrm{V}$ and $\mathrm{D}$ were taken into consideration. In V, special concern as to the consistent placement, right proportion and correspondence to the comments has been given for the diagrams in the margins around the text of the commentary. In D, by contrast, the diagrams were drawn after the text of the scholia was copied, but no care was taken to position them in accordance with the respective text.

As can be seen from Table 2, six groups of logical diagrams pertaining to Anal. Pr. II can be distinguished. There are diagrams that could derive either (a) from the text of Magentenos, or (b) from the text of Magentenos or Aristotle, or (c) from the text of Magentenos or Ps.-Philoponos. Then there are (d) diagrams which have the Aristotelian text as their source, and (e) diagrams related to the scholia of Ps.-Philoponos. From a total of 129 diagrams, 33 actually or possibly derive from the scholia of Magentenos, but only 5 diagrams of this group are transmitted in both hyparchetypes.

Table 1: Diagrams in V and $D$

\begin{tabular}{l|l|l|l|l}
\hline & V & D & Common & Total \\
(a) Magentenos & 10 & 8 & 5 & 23 \\
(b) Magentenos / Aristotle & - & 6 & - & 6 \\
(c) Magentenos / Ps.-Philoponos & 2 & 2 & - & 4 \\
Subtotal & 12 & 16 & 5 & 33 \\
(d) Aristotle & 31 & 47 & 6 & $\mathbf{8 4}$ \\
(e) Ps.-Philoponos & 1 & 8 & 3 & 12 \\
Total & 44 & 71 & 14 & 129 \\
\hline
\end{tabular}

Only diagrams in the first three groups have been used for the present edition. Because of the aforementioned loose connection between diagrams and text, the former are 
edited in Appendix A. They are related to the commentary by means of the apparatus diagrammatum, while every diagram in Appendix $A$ is supplied with the respective reference of the latter apparatus. The remainder of the diagrammatic material, namely the diagrams of groups 'd' and 'e', are edited in the Appendices $B$ and $C$ respectively. Different colours are used for providing 'critical' information related to the drawings: black for common features; red for omissions in D; violet for omissions in V; blue for different diagrams of the same argument in either manuscript; and olive for additions in D. Simple footnotes are employed for variants regarding the captions. Diagrams copied in the second ductus of $\mathrm{V}$ bear an asterisk $\left(^{\star}\right)$ after the number of the respective reference.

\subsection{Readings of Anal. Pr. II}

The purpose of the following survey of variants is to trace the general traits of the Aristotelian text employed by Leon Magentenos in his commentary on Anal. Pr. II. The following chronological list of thirteen vetustissimi and vetusti that transmit Anal. Pr. II may, however, not be comprehensive, should in the light of new evidence, other codices be dated as contemporaneous with Magentenos. ${ }^{11}$

- Ambr. L 93 sup., 9th/10th c., ff. 149r-189v (= n)

- $\quad$ Vat. Barb. gr. 87, 9th/10th c., ff. 92r-120v (= R $)^{12}$

- Sinait. gr. NEM 138, beginning of the 10th c., f. $7 \mathrm{rv}(=\mathrm{N}) .{ }^{13}$ The fragment transmits

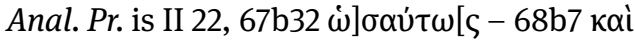

- Vat. Urb. gr. 35, 902/903, ff. 159r-192v (= A) ${ }^{14}$

- Marc. gr. 201, 954, ff. 68v-85r (= B)

- Laur. 72.5, second half of the 10th c. ff. 150r-152v (= d). ${ }^{15}$ From Anal. Pr. II 26, 69b4

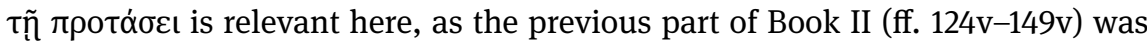
copied by a scribe of the second half of the thirteenth century.

- $\quad$ Athous Laur. H 23, 11th c., ff. 47v-95v (= H)

$\mathbf{1 1}$ The dates of the manuscripts were taken from the respective manuscript catalogues and the bibliography referenced below. On the textual tradition of the Anal. Pr. see Waitz 1844, 1-29; Ross 1949, 87-95; Minio-Paluello 1964, v-x; Williams 1984, 1-8, 80-101; Brockmann 2004, 50-63; Ebert - Nortmann 2007, 177-179. On the most important manuscripts transmitting the Anal. Pr. see Brockmann 2004, 51-52.

12 Link to the online digitised copy of $D V L$ on p. XXII. The manuscript bears the siglum V in the editions of Brunschwig 1967, Brunschwig 2007, Bodéüs 2001 and Weidemann 2014. In contrast, the siglum $\mathrm{R}$ was employed in Montanari 1984 and Montanari 1988. In our edition V is assigned to Vat. gr. 244, so we have consequently opted for the siglum $R$.

13 In Reinsch 2001 the Sinaiticus was given the siglum S. We have assigned the siglum N, since in our edition $S$ is attributed to Par. Coisl. 167.

14 Link to the online digitised copy of $D V L$ on $\mathrm{p}$. XXII.

15 Link to the online digitised copy of TECA Digitale on p. XXII. 
- Par. Coisl. 330, 11th c., ff. 115v-149v (= C $)^{16}$

- Vat. gr. 1024, 11th c., ff. 16v-64v (= c $)^{17}$

- Laur. CS 192, first half of 12th c., ff. 60r-73r (=1)

- Guelf. 24 Gud. graec., 12th c., ff. 59v-84v (= g); ${ }^{18}$ with text loss of Anal. Pr. II 21, 67 a35 ö́ око - 22, 68a11 tò A

- $\quad$ Taur. C III 18, 12th, ff. 233r-318v (= T)

- Bas. F II 21, second half of 12th c. to first half of 13th c., ff. 91v-121v (= u)

M. Williams's study on $\mathrm{ABdCc}^{19}$ is very helpful, but it contains some incorrect and several confusingly cited readings. Waitz on the other hand, collated only parts of the Anal. Pr. in u. ${ }^{20}$ Thus, we provide concerning the Aristotelian variants in the text of Magentenos new collations for all seven manuscripts. D. Reinsch's collations were taken into consideration for $\mathrm{N} .{ }^{21} \mathrm{RHlgT}$ are collated here for the first time. ${ }^{22}$

We have classified the Aristotelian readings into two overlapping groups, which include seven subgroups:

I. Citation
(a) typical lemmata attached to the beginning of scholia (e.g. schol. 1, 2, 3, 13 etc.)
(b) lemmata with wording interrupted at times by brief remarks (introductive or explanatory), or by syntactic adaptations (e.g. schol. 5, 29, 37, 40 etc.)
(c) quotations of Aristotelian text within the scholia
(d) readings based on syntactically modified Aristotelian text

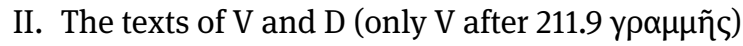

(a) common readings identical with variants of one or more Organon manuscripts

(b) common readings that differ from the Aristotelian text

(c) different readings, each of them transmitted by at least one textual witness of Anal. Pr. II.

All variants are listed below. Every entry begins with a scholion-number and ends with a reference to the pages of the Bekker edition, followed by a ' $\|$ '. A quantitative overview is illustrated in Table 3 (p. LXXXIX).

\footnotetext{
16 Link to the online digitised copy of Gallica on p. XXII.

17 Link to the online digitised copy of $D V L$ on p. XXII.

18 Link to the online digitised copy of WDB on p. XXII.

19 Williams 1984, 33-49.

20 Waitz 1844, 146.

21 Reinsch 2001, 66-67.

22 Manuscripts nRABdClg were collated from digital colour files, whereas microfilms were employed for cHTu.
} 
[The superscript '2' to the right of a siglum (e.g. $C^{2}$ ) refers to interventions (additions, deletions, corrections etc.) made by later hands. Other conventions include: a.c. = ante correctionem; add. = addidit; a.r. $=$ ante rasuram; cancel. $=$ cancellavit; i.m. $=$ in margine; i.r. $=$ in rasura; om. $=$ omisit; p.c. $=$ post correctionem; p.r. = post rasuram; s.l. $=$ supra lineam; transp. $=$ transposuit.]

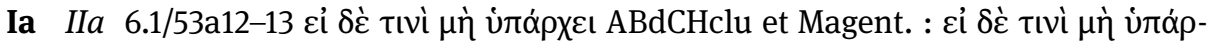

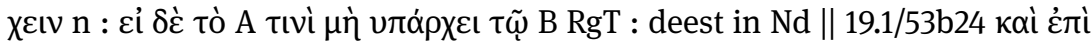

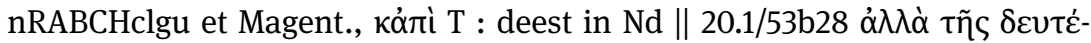
pas nRACHclgT et Magent. : om. Bu : add. B2 s.l. : deest in Nd || 35.1/57b28 $\delta$ ' $(\delta \dot{\varepsilon})$ nRABCclgTu et Magent. : om. $\mathrm{H}$ : deest in Nd || 38.1/58a27-28 $\dot{\eta}$ yò $\rho$

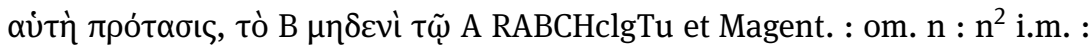

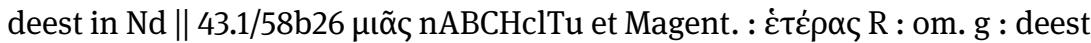

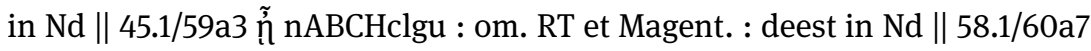

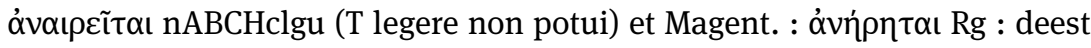

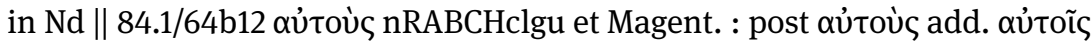

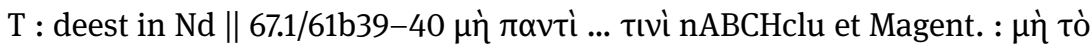

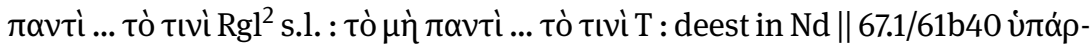

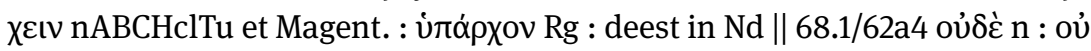
RABCc ${ }^{2}$ l, fortasse g s.l., T et Magent. : oũ Hcu : deest in $\mathrm{Nd}$ : oủ $\delta \dot{v} v$ scripsit Ross

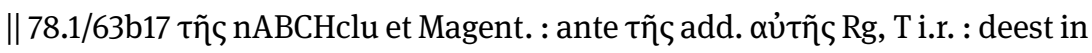

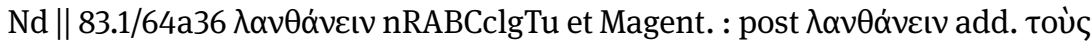

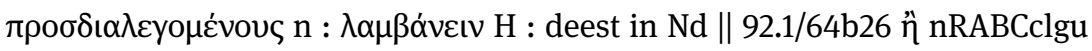

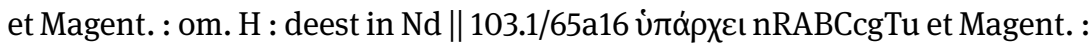

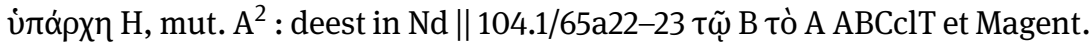

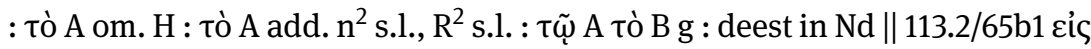

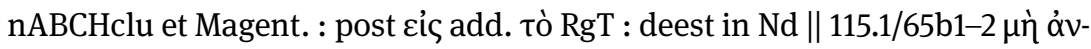

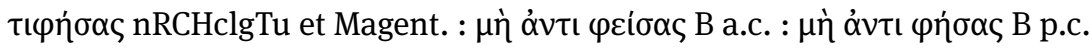

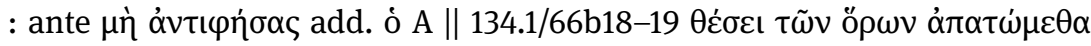

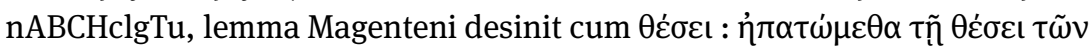

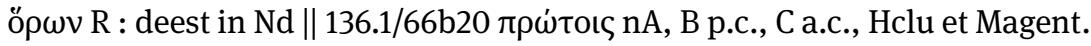

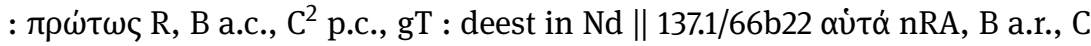

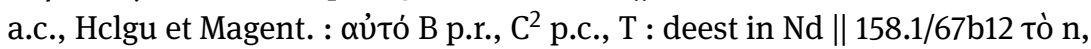
$\mathrm{A}^{2}$ p.r., B, fortasse $\mathrm{C}$ p.r., c, 1 p.c., Tu et Magent. : $\tau \tilde{\omega} \mathbf{~ A ~ a . r . , ~ f o r t a s s e ~ C ~ a . r . , ~ H , ~} 1$

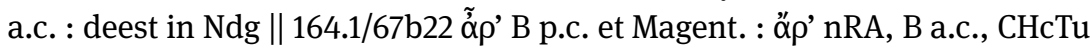

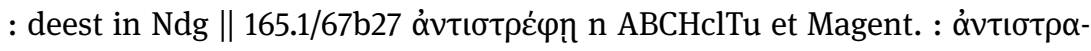
$\varphi \tilde{n} \mathrm{R}$ : deest in Ndg || 182.1/68a16 tò nRClgT et Magent. : om. NABHcu : deest

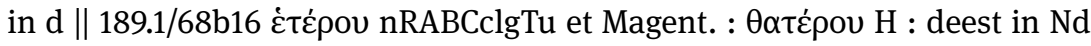

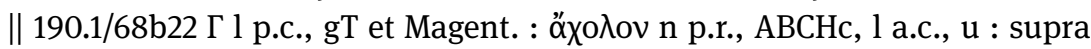

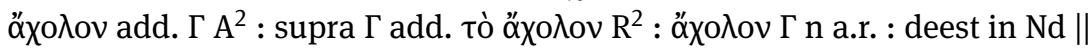
194.1/68b35 oũv nRABHclgTu et Magent. : om. Cl : deest in Nd || 194.1/68b35-

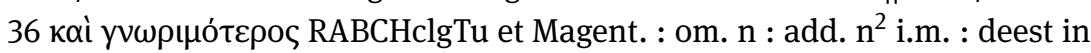

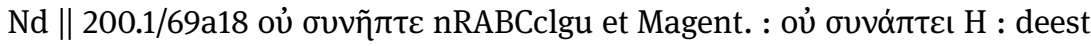
in Nd || 207.1/69a18 tò nRABdCHcgTu et Magent. : tì 1 : deest in N || 215.1/70a9 


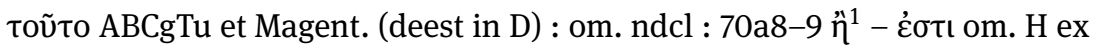

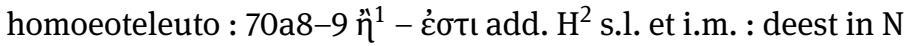

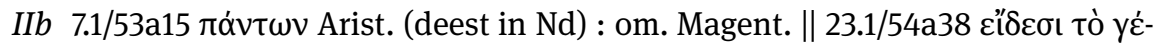

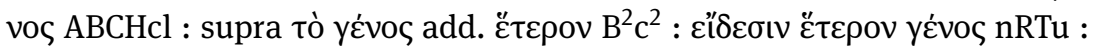

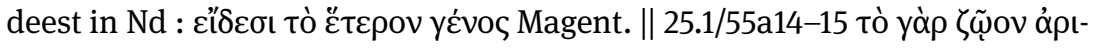

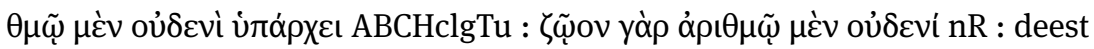

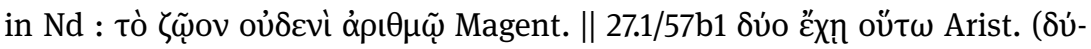

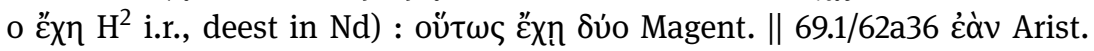

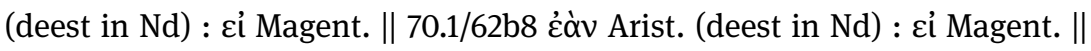

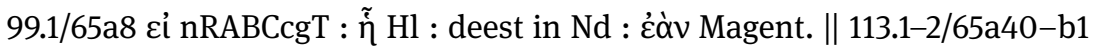

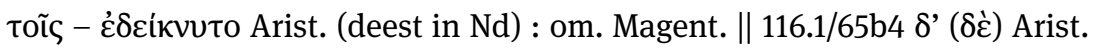

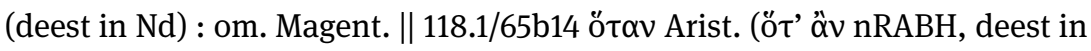

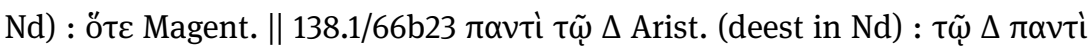

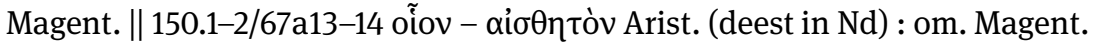

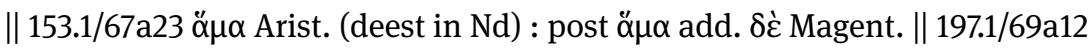
$\tau \tilde{\omega} v$ Arist. (deest in Nd) : om. Magent. || 214.1/70a7 yó $\rho$ Arist. (deest in N) : om.

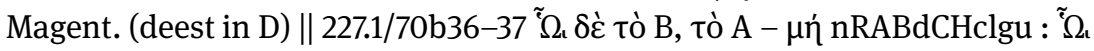

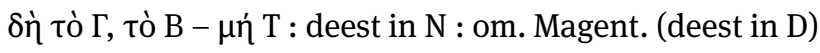

IIc -

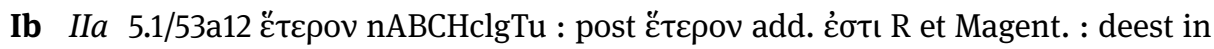

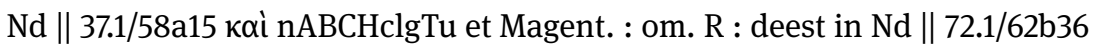

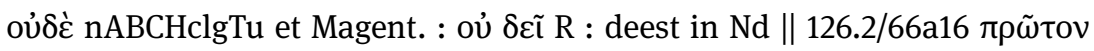
nRACHlgu et Magent. : om. Bc : add. $B^{2}$ s.l., $c^{2}$ s.l. : deest in Nd \|148.1/67a6 ن́-

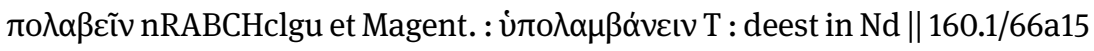

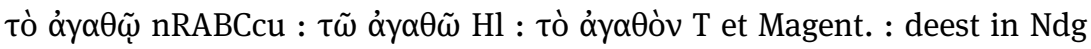
\| 160.1/66a15 $\Gamma^{1}$ nABCHclu et Magent. : ante $\Gamma^{1}$ add. tò $\mathrm{R}$ : deest in Ndg \|

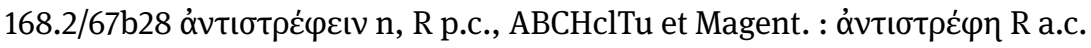
: deest in $\mathrm{Ndg}$

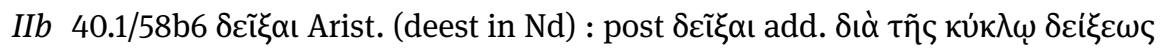

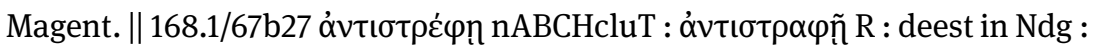

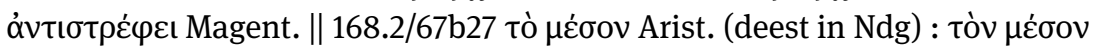

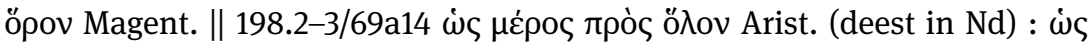

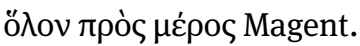

IIc -

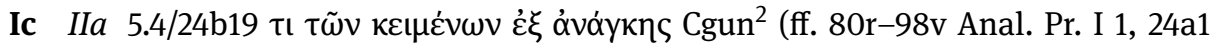
- 10, 31 a17 a librario s. XIV scripta sunt), $A^{2}$ i.r., $d^{2}$ i.r. et Magent. : $\tau \iota \tau \tilde{\omega} v$

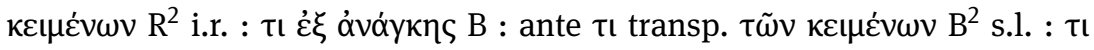

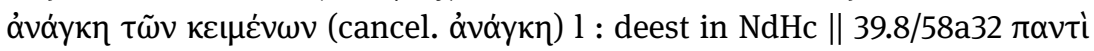

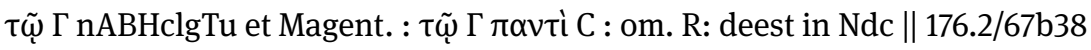

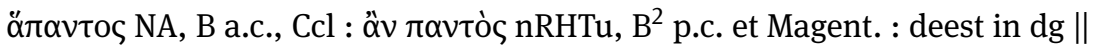
176.5/68a1 A ... Г N, A p.c., B p.c., H, c p.c., 1, T p.c., lemma Magenteni desinit cum A : Г ... A nR, A a.c., B a.c., C, c a.c., T a.c. : deest in dg 


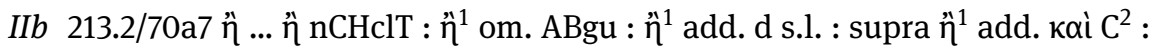

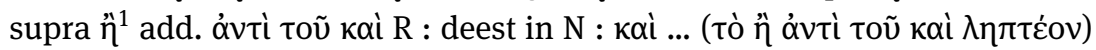
kaì Magent. (deest in D)

IIc -

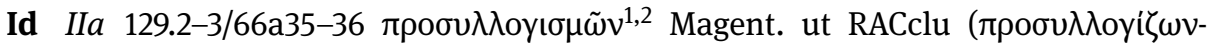

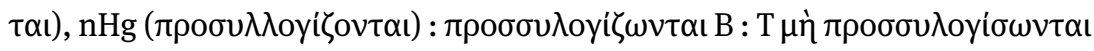
: deest in Nd || 186.2/68b4, 5 ovveĩvaı nR, $\mathrm{N}^{2}$ p.c., ABCHclg Tu et Magent. :

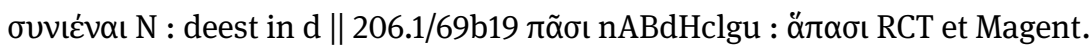

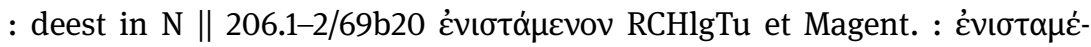

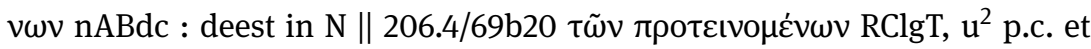

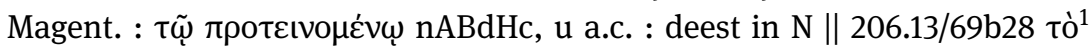
ABcu et Magent. : om. nRdCHlgT : deest in N || 206.16/69b28-29 toủvavtíov

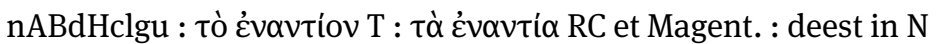

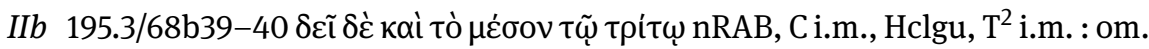

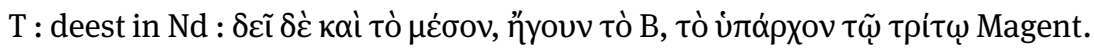

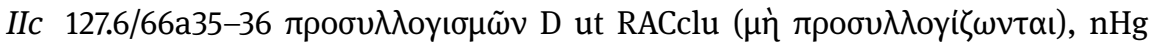

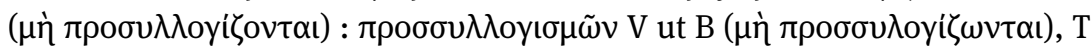

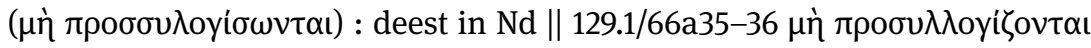

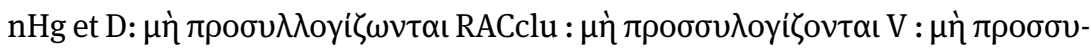

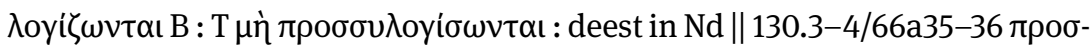

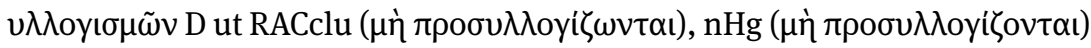

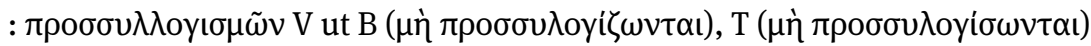
: deest in $\mathrm{Nd} \|$ 144.1/66b39 $\pi \rho \omega ́ \tau \eta v ~ n^{2}$ s.l., RABCHclTu, g ${ }^{2}$ s.l. et V : om. nAg et

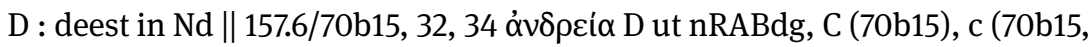

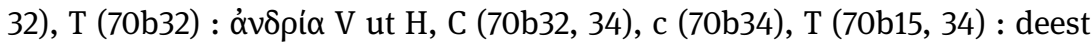

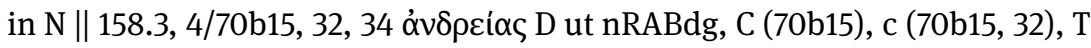

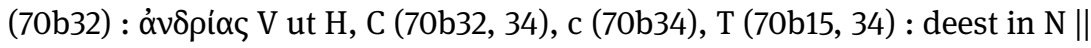

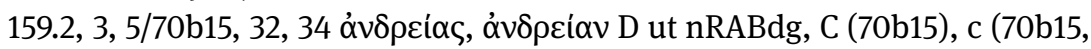

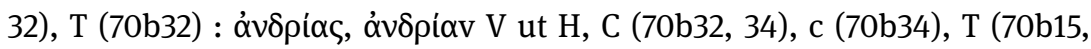

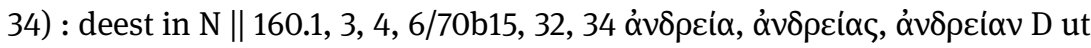

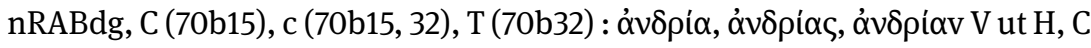

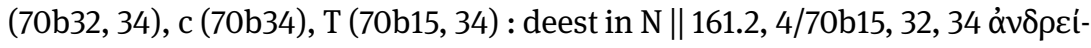

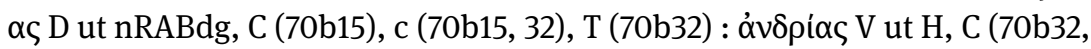
34), c (70b34), T (70b15, 34) : deest in $\mathrm{N} \| 164.2-3,4,6,7,9,11$ bis / 70b15,

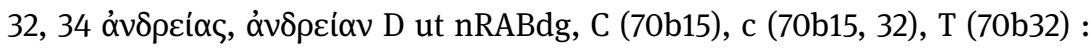

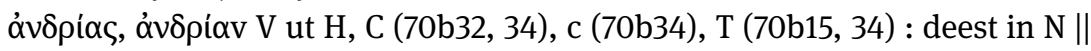

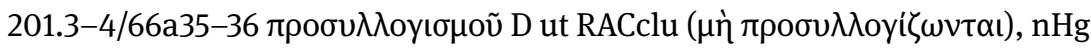

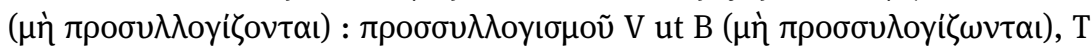

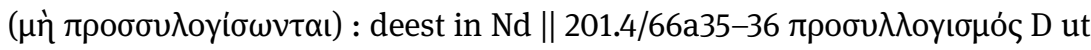

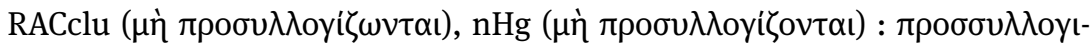

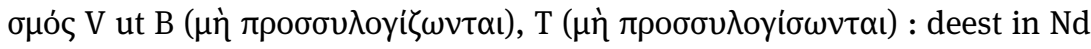

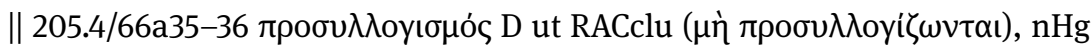




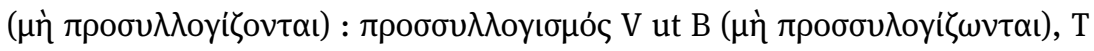
( $\mu$ ’̀ $\pi \rho о \sigma \sigma v \lambda о y i ́ \sigma \omega \nu \tau \alpha \iota):$ deest in $\mathrm{Nd}$

Table 2: Classification of Aristotelian Readings

\begin{tabular}{l|l|l|l|l|l}
\hline & la & Ib & Ic & Id & Total \\
IIa & 33 & 8 & 4 & 7 & 52 \\
IIb & 16 & 4 & 1 & 1 & 22 \\
IIc & - & - & - & 28 & 28 \\
Total & $\mathbf{4 9}$ & $\mathbf{1 2}$ & $\mathbf{5}$ & $\mathbf{3 7}$ & $\mathbf{1 0 2}$ \\
\hline
\end{tabular}

From the 102 Aristotelian readings above, we may infer the following:

- Subgroup IIa:

- 33 readings belong to subgroup Ia. 16 of them are conjunctive errors in both Magentenos and in one or more textual witnesses for Anal. Pr. II (see Table 4 below). We decided to exclude subgroup 1a from the apparatus criticus of our edition, since these lemmata may have been supplemented by later scribes. ${ }^{23}$

Table 3: Conjunctive errors of the Aristotelian tradition and Leon (Subgroup la/Ila)

\begin{tabular}{l|c|c|c|c|c|c|c|c|c|c|c|c|c}
\hline Arist. & $\mathrm{n}$ & $\mathrm{R}$ & $\mathrm{A}$ & $\mathrm{A}^{2}$ & $\mathrm{~B}$ & $\mathrm{C}$ & $\mathrm{c}$ & $\mathrm{c}^{2}$ & $\mathrm{l}$ & $\mathrm{g}$ & $\mathrm{T}$ & $\mathrm{u}$ & Total \\
Magent. & 1 & 1 & 1 & 1 & 2 & 2 & 1 & 1 & 2 & 1 & 2 & 1 & 16 \\
\hline
\end{tabular}

- the remaining 19 readings in subgroup Ia include 10 conjunctive errors between Magentenos and the Aristotelian manuscripts. These readings are cited in the apparatus criticus (see Table 5 on p. XC).

Table 4: Conjunctive errors in the Aristotelian tradition and Magentenos

\begin{tabular}{l|l|l|l|l|l|l}
\hline Arist. & $\mathrm{R}$ & $\mathrm{C}$ & $\mathrm{C}$ & $\mathrm{g}$ & $\mathrm{T}$ & Total \\
Magent. & 4 & 2 & 1 & 1 & 2 & 10 \\
\hline
\end{tabular}

- 22 readings belong to subgroup IIb. These should be considered separative mistakes in the text of Magentenos.

- Subgroup IIc contains 28 readings. These can actually be reduced to 3 separative errors in V and D (see Table 5 below). Two of them are of particular interest:

23 For instance, Magentenos' comments in the vulgata transmit 103 lemmata in a total of 227 scholia, whereas the 55 scholia of the recensio Urbinatis include only 9 lemmata. 


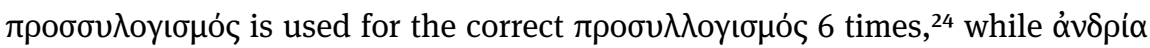
is used for the correct variant $\alpha v \delta \rho \varepsilon i \alpha 21$ times. The variants of $\pi \rho 0 \sigma v \lambda \lambda$ oyı $\sigma \mu$ ó render a different meaning. Additionaly, $\alpha v \delta \rho i \alpha$ is transmitted by three codices from the eleventh and by a manuscript from the twelfth century. All three readings, however, are conjunctive errors between one of the two hyparchetypes and at least one codex containing Anal. Pr. II. The variants of this subgroup are included in the apparatus criticus.

Table 5: Separative errors in VD, i.e. conjunctive errors between respective textual witnesses of Anal. Pr. II and V or D (Subgroup IIc)

\begin{tabular}{|c|c|c|c|c|}
\hline $\begin{array}{l}\text { Arist. } \\
\text { V } \\
\text { D }\end{array}$ & $\begin{array}{l}\mathrm{nAg} \\
- \\
1\end{array}$ & 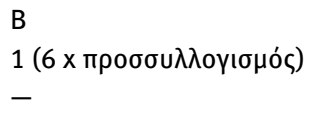 & $\begin{array}{l}\text { CHcT } \\
1(21 \times \dot{\alpha} v \delta \rho i ́ \alpha) \\
-\end{array}$ & $\begin{array}{l}\text { Total } \\
2 \\
1\end{array}$ \\
\hline
\end{tabular}

- $\quad$ Of 29 conjunctive errors in Tables 4-5 (26 + 3 representative readings in subgroup IIc), Magentenos' scholia transmit, in most cases, mistakes in R, C and T (see Table 6 below).

Table 6: Conjunctive errors of the tradition of Anal. Pr. II and Leon

\begin{tabular}{l|l|l|l|l|l|l|l|l|l|l|l|l|l|l}
\hline Arist. & $\mathrm{n}$ & $\mathrm{R}$ & $\mathrm{A}$ & $\mathrm{A}^{2}$ & $\mathrm{~B}$ & $\mathrm{C}$ & $\mathrm{H}$ & $\mathrm{c}$ & $\mathrm{c}^{2}$ & $\mathrm{l}$ & $\mathrm{g}$ & $\mathrm{T}$ & $\mathrm{u}$ & Total \\
Magent. & 2 & 5 & 2 & 1 & 3 & 5 & 1 & 3 & 1 & 2 & 3 & 5 & 1 & $\mathbf{2 9}$ \\
\hline
\end{tabular}

- $\quad$ To the 5 common errors with R [5.1/53a12 (also in T); 45.1/59a3; 176.2/67b 38 (also in T); 206.1/69b19 (also in CT); 206.14/69b28-29 (also in C)] we should add a separative error of Magentenos which seems to have as its premise a reading in Vat. Barb. gr. 87 (see p. LXXXVIII, lc, llb, 213.2/70a7).

24 Although in one occasion both manuscripts transmit the correct form; see schol. 129.2-3. 


\subsection{Conventions}

Sigla

Manuscripts with Leon Magentenos' comments on Anal. Pr. II

D Ambr. D 54 sup. (before 1272)

F Par. gr. 1972 (beginning of the 14th c.)

E Par. Coisl. 157 (after 1330)

K Vat. Reg. gr. 107 (end of the 14th c.)

P Par. gr. 1846 (14th c.)

R Vat. gr. 1018 (15th c.)

S Par. Coisl. 167 (14th c.)

U Vat. Urb. gr. 35 (12th c.)

$\mathrm{U}^{\mathrm{a}}$ Utin. gr. 256 (1301-1325)

V Vat. gr. 244 (12th/13th c.)

t Trincavelli's editio princeps (Venice 1536)

$\alpha$ consensus of $\mathrm{F}$ and $\mathrm{K}$

$\beta$ consensus of $P$ and $R$

Manuscripts of Anal. Pr. II
A Vat. Urb. gr. 35, 902/903
B Marc. gr. 201, 954
C Par. Coisl. 330, 11th c.
$\mathrm{H}$ Athous Laur. H 23, 11th c.
N Sinait. gr. NEM 138, beginning of the 10th c. (Anal. Pr. II 22, 67b32 $\dot{\omega}] \sigma \alpha u ́ \tau \omega[\varsigma-68 b 7$

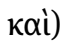
R Vat. Barb. gr. 87, 9th/10th c.
$\mathrm{T}$ Taur. C III 18, 12th c.
c Vat. gr. 1024, 11th c.

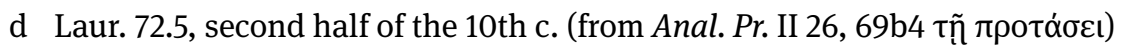
g Guelf. 24 Gud. graec., 12th c. (with text loss of Anal. Pr. II 21, 67a35 پ้токо - 22, 68a11 тò A)
1 Laur. CS 192, first half of 12th c.
n Ambr. L 93 sup., 9th/10th c.
$\mathrm{u}$ Bas. F II 21, second half of 12th - first half of 13th c.

\section{Abbreviations}

$\begin{array}{ll}\text { a.c. } & \text { ante correctionem } \\ \text { add. } & \text { addidit }\end{array}$




$\begin{array}{ll}\text { cf. } & \text { confer } \\ \text { corr. } & \text { correxit } \\ \text { cancell. } & \text { cancellavit } \\ \text { diagr. } & \text { diagramma/diagrammata in appendicem A } \\ \text { f. (ff.) } & \text { folium (folia) } \\ \text { iter. } & \text { iteravit } \\ \text { i.m. } & \text { in margine } \\ \text { i.r. } & \text { in rasura } \\ \text { om. } & \text { omisit } \\ \text { p.c. } & \text { post correctionem } \\ \text { s.l. } & \text { supra lineam } \\ \text { schol. } & \text { scholium, scholia } \\ \text { transp. } & \text { transposuit } \\ \text { v. } & \text { versus } \\ \text { vid. } & \text { vide } \\ & \\ \langle\text { Greek text }\rangle & \text { additions of the editor } \\ \text { [Greek text] } & \text { deletions of the editor }\end{array}$

\section{Writers and Works}

Anal. Pr.

Anon. In Anal. Pr. II

Alex. In Anal. Pr. I

Alex. In Top.

Amm.

Cael.

Cat.

D.I

D.II

D.III

EN
Aristotelis Analytica priora et posteriora, ed. W. D. Ross - L. Minio-Paluello, Oxford 1964.

C. Brandis, Scholia in Aristotelem, Berlin 1836, 187a16188a41, 189b25-190a27, b4-18, 191a7-36, b27-41, 192b25193a5, b6-28, 194a40-47, b36-45, 195b21-25.

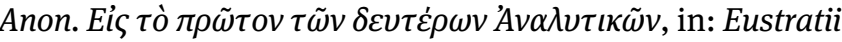
in analyticorum posteriorum librum secundum commentarium [CAG 21.1], ed. M. Hayduck, Berlin 1907, vii-xviii.

Alexandri in Aristotelis analyticorum priorum librum I commentarium [CAG, 2.1], ed. M. Wallies, Berlin 1883.

Alexandri Aphrodisiensis in Aristotelis topicorum libros octo commentaria [CAG, 2.2], ed. M. Wallies, Berlin 1891.

Ammonii in Aristotelis analyticorum priorum librum I commentarium [CAG, 4.6], ed. M. Wallies, Berlin 1899.

Aristote, Du ciel, ed. P. Moraux, Paris 1965.

Aristote, Catégories, ed. R. Bodéüs, Paris 2001.

Prooemion I to Anal. Pr. II on p. 192.

Prooemion II to Anal. Pr. II on p. 193.

Prooemion III to Anal. Pr. II on p. 194.

Aristotelis Ethica Nicomachea, ed. I. Bywater, Oxford 1894. 
Eucl.

Hip.

Iambl.

Ital.

Magent. In Top.

Magent. In Soph. El.

Magent. (?)

Marinus

Meno

Metaph.

Olympiod.

Pedias. I

Pedias. II

Philop. In Anal. Pr. I

Philop. In Anal. Post. I

Philop. In Phys.

Phys.
Euclidis Elementa, vol. I: Libri I-IV cum appendicibus, ed. I. L. Heiberg - E. S. Stamatis, Leipzig $1969^{2}$.

Hippocrates, Aphorismi, in: É. Littré, Oeuvres complètes d'Hippocrate, vol. IV, Paris 1844, 458-608.

[Iamblichi] Theologoumena arithmeticae, ed. V. De Falco, Leipzig 1922.

Ioannes Italos, Quaestiones quodlibetales, ed. P. Joannou, Ettal 1956.

Leontis Magentini in Aristotelis topicorum prooemium et librum secundum commentaria, in: S. Kotzabassi, Byzantinische Kommentatoren der aristotelischen Topik. Johannes Ita-

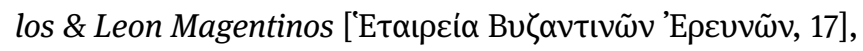
Thessaloniki 1999, 111-152.

Dilectus scholiorum Leonis Magentini in Aristotelis Sophisticos Elenchos, in: S. Ebbesen, Commentator and Commentaries on Aristotle's Sophistici Elenchi. A Study of Post-Aristotelian Ancient and Medieval Writings on Fallacies [Corpus Latinum Commentariorum in Aristotelem Graecorum, 7], vol. I: The Greek Tradition, Leiden 1981, 280-306.

'Leon Magentinos (?), Proömium zu Anal. Pr. I (Princeton MS 173)', in: CAGB Database (https://cagb-digital.de, last accessed on 1 March 2021).

Marinus, On the purpose of Anal. Pr. II, in: N. Agiotis, 'Marinos and the purpose of Prior Analytics II', Parekbolai 6 (2014) 15.

Platonis opera, ed. J. Burnet, vol. III, Oxford 1903 (Stephani vol. II) 70a-100c.

Aristotelis Metaphysica, ed. W. Jaeger, Oxford 1957.

Olympiodori prolegomena et in categorias commentarium [CAG, 12.1], ed. A. Busse, Berlin 1902.

Ioannis Pediasimi In Aristotelis Analytica scholia selecta, ed. V. De Falco, Naples 1926.

V. De Falco, 'Altri Scolii di Giovanni Pediasimo agli Analitici', Byzantinische Zeitschrift 28 (1926) 251-269.

Ioannis Philoponi in Aristotelis analytica priora commentaria [CAG, 13.2], ed. M. Wallies, Berlin 1905, 1-386.

Ioannis Philoponi in Aristotelis analytica posteriora commentaria cum anonymo in librum II [CAG, 13.3], ed. M. Wallies, Berlin 1909, 1-333.

Ioannis Philoponi in Aristotelis physicorum octo libros (tres priores) commentaria [CAG, 16], ed. H. Vitelli, Berlin 1887. Aristotelis Physica, ed. W. D. Ross, Oxford 1950. 
Ps.-Philop.

Rhet.

Schol. in Luc.

Simpl.

Top.
Ioannis Philoponi in Aristotelis analytica priora commentaria [CAG, 13.2], ed. M. Wallies, Berlin 1905, 387-485.

Aristotelis ars rhetorica, ed. W. D. Ross, Oxford 1959.

H. Rabe, Scholia in Lucianum, Leipzig 1906.

Simplicii in Aristotelis de caelo commentaria [CAG, 7], ed. J. L. Heiberg, Berlin 1894.

Aristote, Topiques, ed. J. Brunschwig, Paris, vol. I 1967 / vol. II 2007. 